\title{
LETTER FROM THE EDITOR-IN-CHIEF
}

\section{The Next Twenty-Five Years of JIBS}

A milestone that many journals never achieve is the celebration of their twentyfifth anniversary. For that reason, the articles in this JIBS issue (Volume 25 Number 4) have adopted a retrospective perspective. Similarly, each issue in 1994 included an invited autobiographical essay on Professional Lives in International Business. These historical views illustrate just how far we have progressed both with JIBS and the AIB. But where are we going?

In 1995, and thereafter, JIBS will be read in over 150 countries. These countries hold about $99 \%$ of the world's population. No other business journal is even remotely close to JIBS in its coverage.

One of the things that distinguishes these far flung JIBS readers and AIB members from many others in the academic community is a shared value about the importance of international business. This superordinate perspective links us as individuals to others around the globe, even when we have never met.

Arguably the primary challenge for many of us over the next twenty-five years will be to continue to try to internationalize our own thinking and that of those around us. For academics, at a personal level, this will occur in part through which phenomena we choose to research and write about, whom we interact with, and what we teach.

For most of us, the international perspective is not some sort of specialization, or what we add (time permitting!) in the final class of our courses. We recognize that International Business is the reality of most business practice. It is the single country (domestic) perspective that should be the specialization-and in time, will be.

Over the next twenty-five years, the research and intellectual focus of many academics will shift to encompass international business. Many of our colleagues will "discover" JIBS. Similarly more of the domestically oriented journals will place greater emphasis on the international context of the articles they publish. These will be welcome developments.

At the same time as the international perspective we already share becomes more prevalent, JIBS will be evolving. JIBS' mental map will expand, inevitably becoming more interdisciplinary and more global in terms of the nationality of its authors, and the locations of the firms they study. More significantly, through the example of its authors, JIBS will provide to the newly internationalizing scholars the necessary leadership they require.

Paul Beamish 